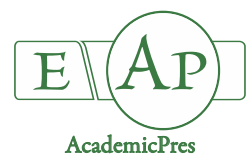

\title{
Genetic Diversity of some Daffodil (Narcissus L. spp.) Genotypes from Turkey by Using SRAP Markers
}

\author{
Emrah ZEYBEKOĞLU*, Tansal KAYGISIZ ASCIOGUL, Hulya ILBI, \\ Mustafa E. OZZAMBAK
}

University of Ege, Faculty of Agriculture, Department of Horticulture, Bornova, Izmir,Turkey; zeybekoglu@gmail.com ( ${ }^{*}$ corresponding author); tanselkaygisiz@gmail.com; bulyailbi@gmail.com;m.ercan.ozzambak@ege.edu.tr

\begin{abstract}
Daffodil (Narcissus L. spp.) is one of the oldest ornamental flowers that have been cultivated from ancient times to nowadays. The species Narcissus tazetta L. and N. serotinus L. have spread out in different regions of Turkey and some other species have been naturalized. The purpose of this study was to characterize some daffodil populations that were collected from different regions of Turkey by using SRAP markers. Twenty-two daffodil populations of different species such as $N$. tazetta, $N$. serotinus, $N$. pseudonarcissus L., $N$. poeticus L. and $N$. jonquilla L. were used. Thirty-seven of 48 SRAP primer combinations showed scorable and polymorphic bands between samples. The similarity coefficients were used to construct a dendrogram by Unweighted Pair-Group Method with Arithmetic Averages (UPGMA) using NTSYS-PC. Cophenetic correlation between ultrametric similarities of tree and similarity matrix were high $(\mathrm{r}=0.97)$. The genotypes of Narcissus species were divided into 2 main groups. Although there was less genetic variation among $N$. tazetta species, even collected from different regions of Turkey, $N$. poeticus, $N$. pseudonarsis, $N$. jonquilla and $N$. serotinus had more genetic divergence among them. It can be concluded that genetic variation of Narcissus species can be used for daffodil breeding programs.
\end{abstract}

Keywords: flower bulb; genetic relationships; populations; SRAP

\section{Introduction}

Daffodils (Narcissus L.), members of family of Amaryllidacea, are bulbous plants of great ornamental value that spread out in the Mediterranean basin (Rivera et al., 2003). While several species are only known under cultivation (Wylie, 1952), the number of wild daffodils ranges between 40-60 species, depending on the species concept used (Jimenez et al., 2009). It has been reported that around 60 Narcissus species spread out all over the world. But the highest diversity of daffodils has been seen in Iberian Peninsula. In addition to this, the species of $N$. tazetta does not only take place in Spain and North Africa but also in China and Japan (Mathew, 2002).

The species $N$. tazetta and $N$. serotinus are also spread out in different regions of Turkey (Davis, 1984). In Roman times, cultivation of daffodils took place in southern Anatolia (Izmir, Antalya) and in times of Ottoman Empire, many horticultural forms were cultivated in Istanbul. Narcissus orientalis, $N$. byzantinus and $N$. constantinopolitanus were all ancient forms of $N$. tazetta which were moved to Europe from Istanbul (Baytop and Mathew, 1984). Although some different species of Narcissus are grown in Turkey, $N$. tazetta is the most commonly grown species for its attractive flower clusters and its special fragrance. Besides these species, there are also some species naturalized. One of them is the double form of $N$. pseudonarcissus naturalized in Belgrat Forest near Istanbul while $N$. papyraceus Ker Gawl. is naturalized in Izmir (Baytop and Mathew, 1984; Davis, 1984). Natural spread of wild species, naturalization of some species, cultivation since ancient times and being the source of some cultivars which were sent to Europe (Baytop and Mathew, 1984; Davis, 1984) reveals the genetic diversity of daffodils in Turkey.

Although Narcissus species have been cultivated for many centuries and spread out all over the world, there is still taxonomic intricacy due to recurrent process of long established cultivation and selection, and subsequent renaturalization as well as the widespread occurrence of hybridization between species. However, Narcissus species have only few morphological differences that can be used for consistent taxonomic frameworks (Jimenez et al., 2009). For the future breeding programs, the available genetic 
1294

pools and the conservation of the wild types are very important. Morphologic and molecular characterizations of the plant germplasm are important to make plant collection useful for breeders and conserve useful diversity of crop for utilization in crop improvement program (Upadhyaya et al., 2002). Therefore, molecular marker technologies, providing robust and independent data have been used for molecular characterization and classification in different plant species. But there is restricted number of studies on molecular variation among Narcissus species (Perez-Baralles et al., 2003; Barrett et al., 2004; Tucci et al., 2004; Graham and Barrett, 2004; Jimenez et al., 2009). However there is no molecular characterization data on Narcissus species of Turkey.

Therefore, the aim of this study was to assess the molecular classification of Narcissus species in Turkey and to determine their genetic relationship. This would be helpful for taxonomic research as well as for genetic conservation and evaluation for further breeding programs. One of the PCR based markers, sequence-related amplified polymorphism (SRAP), was used to evaluate genetic diversity in this study. SRAP technique employs a combination of two primers, a forward primer of 17 bases, and a reverse primer of 18 bases, which consisted of preferential amplification of open reading frames (ORFs) and was developed for mapping and gene tagging in Brassica by $\mathrm{Li}$ and Quiros (2001). The observed polymorphism fundamentally originated in the variation of the length of introns, promoters, and spacers, both among individuals and among species (Li and Quiros, 2001). SRAP has been successfully used for evaluation of genetic diversity (Ferriol et al., 2003), comparative genomics analysis and map construction (Li et al., 2003).

\section{Materials and Methods}

The plant material consisted of 22 daffodil genotypes collected from natural distribution areas, from naturalized places in where daffodils plantation has been growing for years and from cultivated areas in different regions of Turkey (Fig. 1). The location data and flower type of the samples were given in Table 1 .

\section{Molecular analysis \\ DNA extraction}

Genomic DNA was extracted from young daffodil leaves by using modified CTAB protocol according to Doyle and Doyle (1990). Leaf tissue was taken into $1.5 \mathrm{ml}$ tubes and crushed using a small plastic bar in liquid nitrogen. CTAB $(0.7 \mathrm{ml})$ buffer was added into the tubes, and then they were incubated at $65^{\circ} \mathrm{C}$ for 60 minutes. After the incubation step $0.7 \mathrm{ml}$ of chloroform + amyl alcohol mix was added and the tubes centrifuged at $11.000 \mathrm{rpm}$ for ten minutes. The supernatant was transferred into a new tube and $0.7 \mathrm{ml}$ of chloroform-amyl alcohol was added and centrifuged again. After centrifugation the supernatant was transferred into a new tube and DNA was precipitated in 2propanol. The DNA was washed with $70 \%$ ethanol + ammonium acetate and then dried and dissolved in TE buffer. DNA concentration was measured by spectrophotometer and adjusted $10 \mu \mathrm{l} / \mathrm{ng}$ using TE buffer.

\section{PCR protocol and gel analysis}

In this study, in total 48 SRAP primer combinations (Table 2 and Table 3) were used. PCR was carried out in 15 $\mu$ reaction volumes containing: $2,5 \mathrm{mM}$ of each primers, $250 \mu \mathrm{M}$ of each dNTP, 1.5 $\mu$ l of 10x PCR Buffer (Fermentas), $2 \mathrm{mM}$ of $\mathrm{MgCl} 2,1$ unit of Taq polymerase and $25 \mathrm{ng}$ of DNA template. The amplification reaction was carried out using a Thermo-cycler Mastercycler (Eppendorf-Germany) with an initial denaturation step at $94^{\circ} \mathrm{C}$ for $3 \mathrm{~min}$, followed by 5 cycles of $1 \mathrm{~min}$ at $94^{\circ} \mathrm{C}, 1$ min at $35^{\circ} \mathrm{C}, 1 \mathrm{~min}$ at $72^{\circ} \mathrm{C}$, the PCR then continued for additional 29 cycles with an annealing temperature of $50^{\circ} \mathrm{C}$ and finalized one cycle of $5 \mathrm{~min}$ at $72{ }^{\circ} \mathrm{C}$. The PCR products were separated on $2.5 \%$ agarose gel in $0.5 \mathrm{TBE}$ buffer at 90 volt for $4 \mathrm{~h}$ and photographed under UV light for further analysis. As a molecular standard, a $100 \mathrm{bp}$ DNA ladder was used in order to confirm the appropriate SRAP markers.

\section{Data analysis}

Each band was scored as present (1) or absent (0) and data were analysed with the Numerical Taxonomy Multivariate Analysis System (NTSYS-pc) software package (Rohlf, 2000). A similarity matrix was constructed based on Dice's coefficient (Dice 1945), which considers only one to one matches between two taxa for similarity. The similarity matrix was used to construct a dendogram using the UPGMA (unweighted-pair group method arithmetic average) to determine genetic relationships among the germplasm studied. SIMINT module was used to compute a distance matrix. Then, a distance matrix was used to construct a dendogram based on the UPGMA method. In order to see how well a cluster analysis represents the distance matrix, COPH module was used to transform the tree matrix to a matrix of ultrametric distances (a matrix of distances implied by the cluster analysis). MXCOMP module was used to compare these ultrametric distances and distance matrix produced for UPGMA analysis.

\section{Results and Discussion}

Out of the 48 SRAP primer combinations screened, 37 combinations were found as polymorphic and 3 combinations were monomorphic. The 37 polymorphic SRAP primer combinations produced total 154 polymorphic bands ranging size from $100 \mathrm{bp}$ to $1500 \mathrm{bp}$.

Cophenetic correlation between ultrametric similarities of tree and very high similarity matrix $(r=0.979)$ was calculated.

The cluster was divided into 2 main groups with a genetic similarity of $32 \%$ (Fig. 2). The first cluster included species of $N$. tazetta and $N$. serotinus which display a genetic similarity that varied from $62 \%$ to $93 \%$. The genetic distance of the other cluster, including $N$. pseudonarcissus, $N$. poeticus and $N$. jonquilla, varied between $60 \%$ and $82 \%$. The relationships between the genotypes in the gene pool are also shown in two-dimensional and three-dimensional plots by using the data obtained from the factor analysis (Figs. 3, 4).

In the first cluster, the genetic distance among $N$. tazetta genotypes usually varied according to distance between their 
Table 1. Collection data of 22 Narcissus populations included in the present study

\begin{tabular}{|c|c|c|c|c|c|c|}
\hline Number & Sample name & Taxa & $\begin{array}{c}\text { The characteristics of } \\
\text { population }\end{array}$ & Location & $\begin{array}{c}\text { The characteristics of } \\
\text { location }\end{array}$ & Flower type \\
\hline 1 & 1 N. tazetta & N. tazetta L. & Natural distribution & Samsun/Bafra & Natural habitats & Single form \\
\hline 2 & $2 N$. tazetta & N. tazetta L. & Naturalized & Istanbul/Beykoz & Private forest & Single form \\
\hline 3 & 3 N. tazetta & $\begin{array}{l}\text { N. tazetta L. cv } \\
\text { Geranium }\end{array}$ & Naturalized & Istanbul/Beykoz & Private forest & Single form \\
\hline 4 & $4 N$. tazetta & N. tazetta & Natural distribution & Izmir/Seferihisar & Natural habitats & Single form \\
\hline 5 & 5 N. tazetta & N. tazetta & Natural distribution & Izmir/Seferihisar & Agricultural area & Single form \\
\hline 6 & 6 N. tazetta & $\begin{array}{l}\text { N. tazetta subsp. italicus } \\
\text { Ker Gawl. }\end{array}$ & Naturalized & Izmir/Odemis & Home garden & Single form \\
\hline 7 & 7 N. tazetta & N. tazetta & Natural distribution & Muğla/Marmaris & Natural habitats & Single form \\
\hline 8 & 8 N. tazetta & N. tazetta & Natural distribution & Antalya/Bahtili & Agricultural area & Single form \\
\hline 9 & 9 N. tazetta & N. tazetta & Natural distribution & Mersin/Anamur Oren & $\begin{array}{c}\text { Agricultural area, Natural } \\
\text { habitats }\end{array}$ & Single form \\
\hline 10 & 10 N. tazetta & N. tazetta & Natural distribution & Mersin/Tasucu & $\begin{array}{c}\text { Agricultural area, Natural } \\
\text { habitats }\end{array}$ & Single form \\
\hline 11 & 11 N. tazetta & N. tazetta & Natural distribution & Mersin Erdemli & Natural habitats & Single form \\
\hline 12 & $12 N$. tazetta & N. tazetta & Natural distribution & Adana/Karatas & Agricultural area & Single form \\
\hline 13 & 13 N. tazetta & N. tazetta & Natural distribution & Hatay/Isken. Arsuz & Agricultural area & Single form \\
\hline 14 & 14 N. tazetta & N. tazetta & Natural distribution & $\begin{array}{c}\text { Hatay } \\
\text { /IskenderunBelen }\end{array}$ & $\begin{array}{c}\text { Agricultural area, Natural } \\
\text { habitats }\end{array}$ & Double form \\
\hline 15 & $15 N$. tazetta & N. tazetta & Natural distribution & $\begin{array}{c}\text { Hatay /Kirikhan } \\
\text { Karatas }\end{array}$ & Agricultural area & Single form \\
\hline 16 & 16 N. tazetta & N. tazetta & Natural distribution & Diyarbakir/Hazro & Agricultural area & Single form \\
\hline 17 & 17 N. serotinus & N. serotinus & Natural distribution & $\begin{array}{l}\text { Mugla/Marmaris } \\
\text { Beldibi }\end{array}$ & Natural habitats & Single form \\
\hline 18 & 18 N. serotinus & N. serotinus & Natural distribution & Mersin/Anamur Oren & $\begin{array}{c}\text { Agricultural area, Natural } \\
\text { habitats }\end{array}$ & Single form \\
\hline 19 & 19 N. pseudonarcissus & N. pseudonarcissus & Naturalized & Istanbul/Beykoz & Private forest & Double form \\
\hline 20 & 20 N. pseudonarcissus & $\begin{array}{l}\text { N. pseudonarcissus L. cv. } \\
\text { Golden harvest }\end{array}$ & Cultur variety & Izmir / Karaburun & Agricultural area & Single form \\
\hline 21 & $21 N$. poeticus & N. poeticus & Naturalized & Istanbul/Beykoz & Private forest & Single form \\
\hline 22 & $22 N$. jonquilla & N. jonquilla & Naturalized & Istanbul/Beykoz & Private forest & Single form \\
\hline
\end{tabular}

Table 2. Primer sequences used for SRAP analysis of Narcissus populations from Turkey

\begin{tabular}{|c|c|c|}
\hline Primer & Type & Sequence $\left(5^{\prime}-3^{\prime}\right)$ \\
\hline Eml & Reverse & GAC TGC GTA CGA ATT AAT \\
\hline Em2 & Reverse & GAC TGC GTA CGA ATT TGC \\
\hline $\mathrm{Em} 3$ & Reverse & GAC TGC GTA CGA ATT GAC \\
\hline Em5 & Reverse & GAC TGC GTA CGA ATT AAC \\
\hline Em6 & Reverse & GAC TGC GTA CGA ATT GCA \\
\hline Em8 & Reverse & GAC TGC GTA CGA ATT CAC \\
\hline Emll & Reverse & GAC TGC GTA CGA ATT CTA \\
\hline Eml2 & Reverse & GAC TGC GTA CGA ATT CTC \\
\hline $\mathrm{Em} 13$ & Reverse & GAC TGC GTA CGA ATT CTG \\
\hline Eml4 & Reverse & GAC TGC GTA CGA ATT CTT \\
\hline Em15 & Reverse & GAC TGC GTA CGA ATT GAT \\
\hline Mel & Forward & TGA GTC CAA ACC GGA TA \\
\hline $\mathrm{Me} 2$ & Forward & TGA GTC CAA ACC GGA GC \\
\hline Me3 & Forward & TGA GTC CAA ACC GGA AT \\
\hline Me4 & Forward & TGA GTC CAA ACC GGA CC \\
\hline $\mathrm{Me} 5$ & Forward & TGA GTC CAA ACC GGA AG \\
\hline Me6 & Forward & TGA GTC CAA ACC GGA CA \\
\hline $\mathrm{Me} 7$ & Forward & TGA GTC CAA ACC GGA CG \\
\hline Me8 & Forward & TGA GTC CAA ACC GGA CT \\
\hline Me9 & Forward & TGA GTC CAA ACC GGA GG \\
\hline Mel0 & Forward & TGA GTC CAA ACC GGA AA \\
\hline Mell & Forward & TGA GTC CAA ACC GGA AC \\
\hline
\end{tabular}


Table 3. SRAP primer combinations which were used for molecular analysis of daffodil samples from Turkey

\begin{tabular}{ccc}
\hline Em1-me11 & Em1-me3 & Em1-me5 \\
\hline Em1-me4 & Em1-me6 & Em1-me9 \\
Em1-me10 & Em1-me7 & Em1-me8 \\
Em2-me1 & Em2-me2 & Em3-me2 \\
Em2-me4 & Em3-me1 & Em3-me5 \\
Em3-me3 & Em3-me4 & Em3-me12 \\
Em3-me7 & Em3-mel1 & Em4-me6 \\
Em4-me1 & Em4-me3 & Em5-me11 \\
Em4-me7 & Em4-me8 & Em6-me3 \\
Em5-me12 & Em6-me1 & Em7-me8 \\
Em6-me6 & Em6-me7 & Em10-me9 \\
Em8-me9 & Em8-mel1 & Em15-me1 \\
Em10-me13 & Em11-mel1 & Em15-me6 \\
Em17-me11 & Em13-me2 & Em15-me10 \\
Em18-mel1 & Em13-me6 & Em15-me11 \\
\hline
\end{tabular}

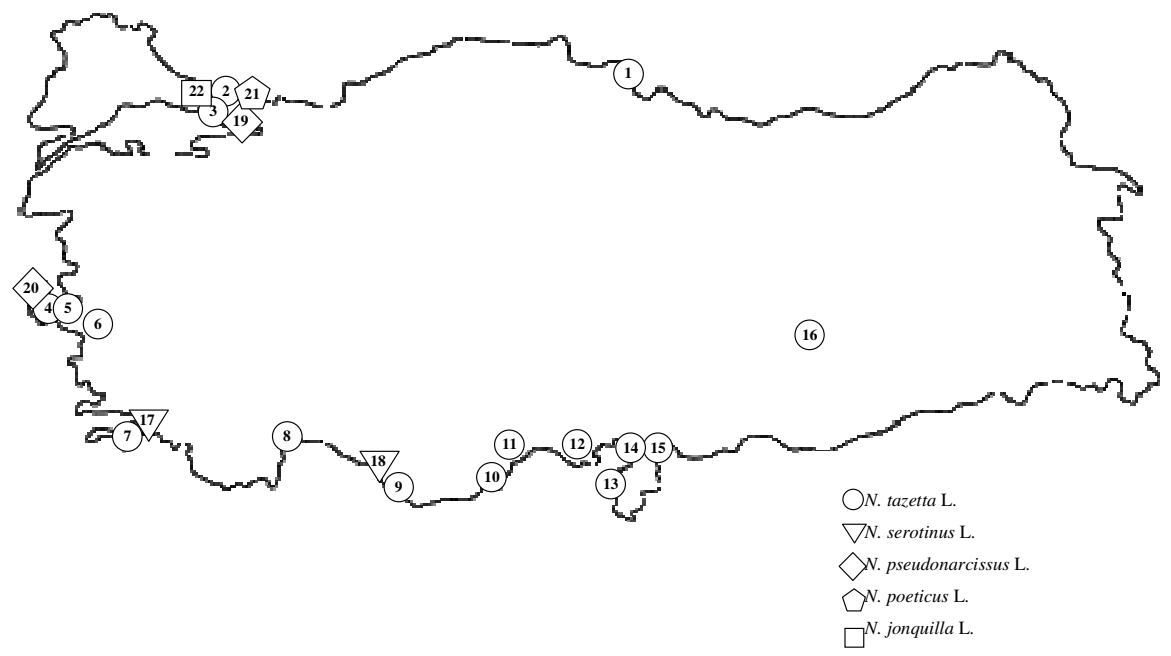

Fig. 1. The daffodil samples of different taxa which collected from different regions of Turkey

regional distributions. Genetically closest genotypes usually originate from closer regions (e.g. 4-5; 8-9; 10-11; 12-1415). The genotypes of N. tazetta from south-west, south (7, $8,9,10,11)$ and south $(12,14,15)$ regions of Turkey had $84 \%$ genetic similarity (Fig. 1). The genotypes (genotype 4 and genotype 5) from Izmir located west part of Turkey were $22 \%$ genetically far from the genotypes from these south regions. The genetically closest genotypes (93\%) were genotype 14 and genotype 15, even though one of them (genotype 14) was double flowered. The genotype 2 naturalized in Istanbul was surprisingly close (92\%) to these genotypes from Hatay $(14,15)$. Although the high distance between two locations, it can be stated that the origin of the genotype 2 may be from Hatay. Genotype 13 was genetically $28 \%$ far from genotypes 14 and 15 , even these 3 genotypes were from same region. However, Davis (1984) stated that some $N$. tazetta species between Iskenderun and Arsuz region (in Hatay) had different morphological properties such as dwarf plant with thin leaves. It can be stated that high genetic variation among genotypes in Hatay region may have resulted from the morphological differences that Davis (1984) pointed out. The genetic similarity of the genotypes 1 and 16 from north and south (Samsun and Diyarbakir), which may be considered to be genetically far (26\%) from other $N$. tazetta genotypes, was $84 \%$ (Fig. 2).

The genotype 3 ( $N$. tazetta cv 'Geranium'), which is a multiheaded cultivar, had a genetically close relation with most of the $N$. tazetta genotypes $(2,7,8,9,10,11,12,14$, 15), having genetic distance of $84-85 \%$. This result confirmed that multiheaded cultivars, which are usually called Poetaz group, are an intersectional hybrid of $N$. tazetta and N. poeticus species (Doorenbos, 1954). Geranium cultivar was found to be genetically closer to $N$. tazetta than to $N$. poeticus. This may be due to the dominant effect of the $N$. tazetta parent in hybridization. However, Geranium cultivar is also morphologically much more similar to $N$. tazetta than $N$. poeticus with its multi flowered stem, and corona colour. 
The genotype 6, N. tazetta subsp. Italicus, showed a genetic similarity ratio of $68 \%$ to $N$. tazetta species.

Narcissus serotinus species (genotype 17 and genotype 18) had about $62 \%$ of genetic similarity to $N$. tazetta species. Genetic closeness between $N$. serotinus and $N$. tazetta species may be expected a supportive result for their botanical classifications, where these two species belong to Hermione subgenus of Narcissus genus (Mathew, 2002).

In the second cluster, the genetic similarity of the genotype 19 (Narcissus pseudonarcissus from Istanbul) and genotype 20 ( $N$. pseudonarcissus. cv. 'Golden' harvest from Izmir) was $82 \%$, in spite of the morphological differences (single and double flower forms) of these genotypes. Wild forms have been usually reported to have single flowers. Double types may have been produced by the duplication of the number of tepals, by changes involving the corona, or changes in the whole flower (Nunez et al., 2003). Also, Baytop and Mathew (1984) mentioned that a double formed flower of $N$. pseudonarcissus was naturalized in Istanbul. Therefore it can be stated that the genotype 19 may be originated from single flowered of $N$. pseudonarcissus. The genotype $22, N$. jonquilla from Istanbul showed $60 \%$ of genetic similarity to genotypes of $N$. poeticus and $N$. pseudonarcissus species.

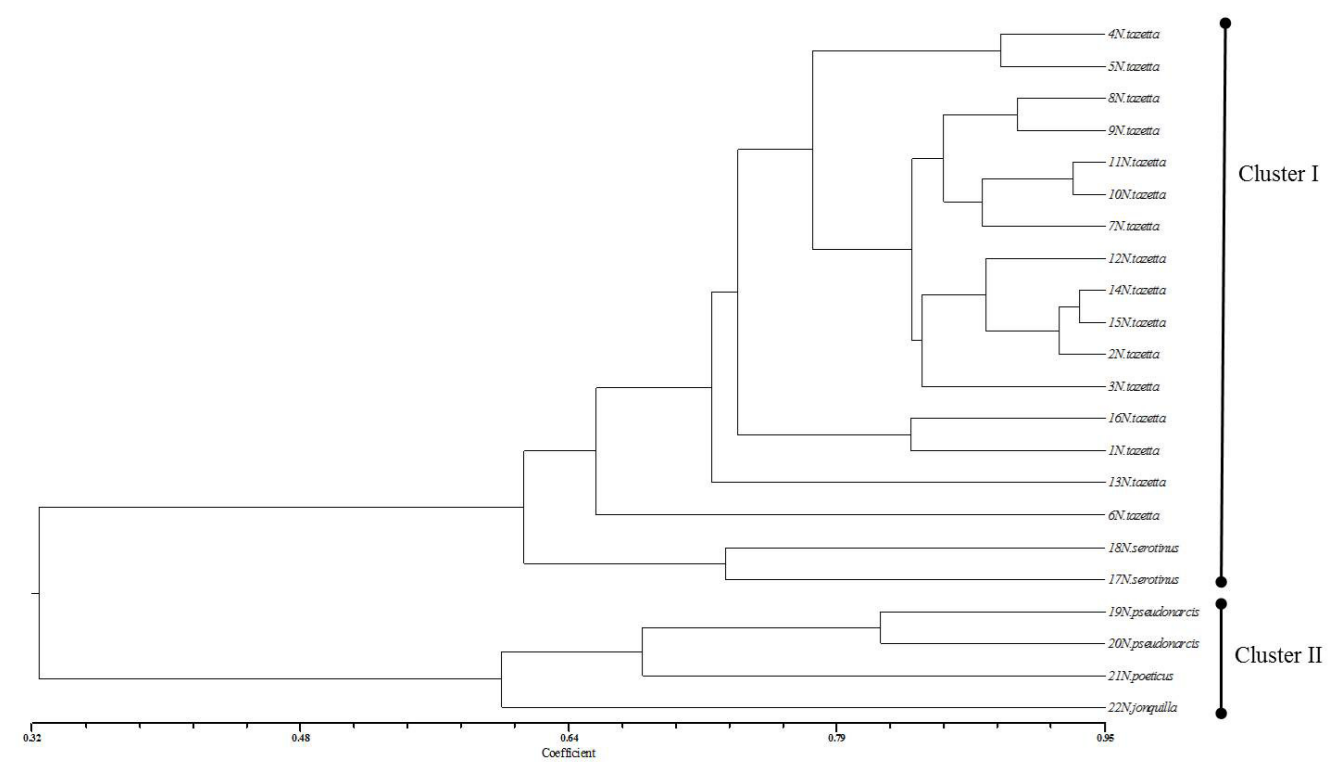

Fig. 2. UPGMA Cluster analysis of 22 daffodil samples from Turkey using 37 polymorphic SRAP combinations

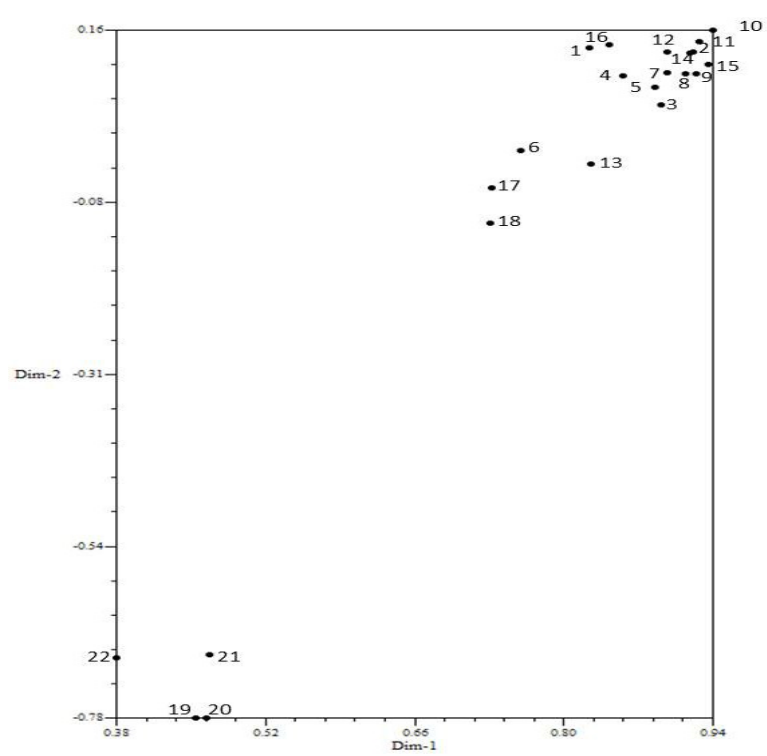

Fig. 3. Two-dimensional plane created by obtained axes from basic component analysis of relations between daffodil genotypes from Turkey

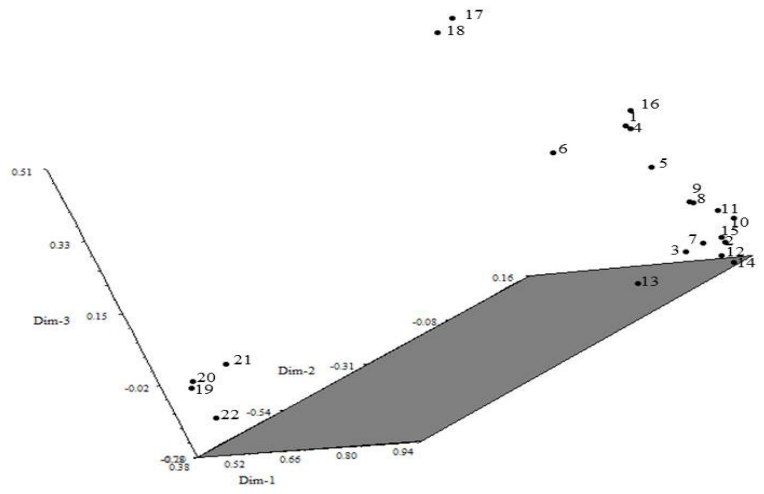

Fig. 4. Three-dimensional plane created by obtained axes from basic component analysis of relations between daffodil genotypes from Turkey 
1298

\section{Conclusions}

In conclusion, there was low genetic variation among $N$. tazetta species even collected from different region of Turkey. In contrast to this, $N$. poeticus, $N$. pseudonarsis, $N$. jonquilla and $N$. serotinus, showed more genetic divergence among them as an expected result as they are not closely related species to $N$. tazetta. Genetic distances of some of the $N$. tazetta samples from the other samples of the same species were also remarkable. This genetic background can be used for daffodil breeding program to widen genetic basis. Also, this paper is the first report on molecular classification of daffodil (Narcissus) species of Turkey. In this research we showed that SRAP markers can be used molecular characterization of Narcissus species and breeding purposes.

\section{Conflict of Interest}

The authors declare that there are no conflicts of interest related to this article.

\section{References}

BarrettSCH, Cole WW, Herrera CM (2004). Mating patterns and genetic diversity in the wild daffodil Narcissus longispathus (Amaryllidaceae). Heredity $92(5): 459-465$.

Baytop T, Mathew B (1984). The bulbous plants of Turkey. BT Batsforf Ltd. London.

Davis PH (1984). Flora of Turkey and the East Aegean Islands. Volume 8. Edinburgh University Press, Edinburgh.

Dice LR (1945). Measures of the amount of ecologic association between species. Ecology 26(3):297-302.

Doorenbos J (1954). Notes on thehistory of bulb breeding in the Netherlands. Euphytica3(1):1-8.

Doyle JJ, Doyle JL (1990). Isolation of plant DNA from fresh tissue. Focus 12(13):13-15.

Ferriol M, Pico B, Nuez F (2003). Genetic diversity of a germplasm collection of Cucurbita pepo using SRAP and AFLP markers. Theoretical and Applied Genetics 107(2):271-282.
Graham SW, Barrett SCH (2004). Phylogenetic reconstruction of the evolution of stylar polymorphisms in Narcissus (Amaryllidaceae). American Journal of Botany 91(7):1007-1021.

Jimenez JF, Sanchez-Gomez P, Guerra J, Molins A, Rosello JA (2009). Regional speciation or taxonomic inflation? The status of several narrowly distributed and endangered species of Narcissus using ISSR and nuclear ribosomal ITS markers. Folia Geobotanica 44(2):145-158.

Li G, Quiros CF (2001). Sequence-related amplified polymorphism (SRAP), a new marker system based on a simple PCR reaction: its application to mapping and gene tagging in Brassica. Theoretical and Applied Genetics 103(2-3):455-461.

Li G, Gao M, Yang B, Quiros CF (2003). Gene for gene alignment between the Brassica and Arabidopsis genomes bydirect transcriptome mapping. Theoretical and Applied Genetics 107(1):168-180.

Mathew B (2002). Classification of the genus Narcissus. Narcissus and Daffodil. Hanks GR(Ed). Taylor \& Francis pp 30-52.

Nunez DR, De Castro CO, Ruiz SR, Ariza FA (2003). The origin of cultivation and wild ancestors of daffodils (Narcissus subgenus Ajax) (Amaryllidaceae) from an analysis of early illustrations. Scientia Horticulturae 98(4):307-330.

Perez-Barrales R, Vargas P, Arroyo J (2003). Convergent evolution of flower polymorphism in Narcissus (Amaryllidaceae). New Phytologist 161(1):235-252.

RohlfFJ (2000). NTSYS-pc, numerical taxonomy and multivariate analysis system, version 2.11. New York, Exeter, Setauket.

Tucci GF, Winfield MO, D’amato GF, Gregori C, Trombetta B, De Dominicis RI (2004). Genetic diversity in Narcissus poeticus L. and N. radiiflorus Salisb. (Amaryllidaceae) in two different populations: AFLP and karyological studies. Caryologia 57(4):405-411.

Upadhyaya HD, Bramel PJ, Ortiz R, Sing, S (2002). Geographical patterns of diversity for morphological and agronomic traits in the groundnut germplasm collection. Euphytica 128(2):191-204.

Wylie AP (1952). The history of the garden Narcissi. Heredity 6(2):137156. 